\title{
Profil Hemodinamik Anak dengan Sindrom Syok Dengue Berdasarkan Pemeriksaan Ultrasonic Cardiac Output Monitor
}

Ida Bagus Gede Suparyatha, Siska Permanasari Sinardja, I Nyoman Budi Hartawan, I Wayan Gustawan, Dyah Kanya Wati, I Made Gede Dwi Lingga Utama

Departemen Ilmu Kesehatan Anak Fakultas Kedokteran Universitas Udayana/ RSUP Sanglah, Denpasar

Latar belakang. Pemantauan hemodinamik secara klinis masih merupakan tantangan klinisi dalam menangani kasus Sindrom syok dengue (SSD) anak. Pengukuran parameter hemodinamik dengan USCOM dapat menilai fungsi jantung dan status hemodinamik secara kuantitatif dan real-time, dengan harapan intervensi adekuat dapat diberikan untuk mengurangi morbiditas.

Tujuan. Mengetahui profil hemodinamik secara kuantitatif pada anak dengan SSD.

Metode. Penelitian ini merupakan pilot study pada tahun 2016 dengan mengukur parameter hemodinamik menggunakan USCOM. Pengukuran dilakukan saat awal terdiagnosis SSD selama perawatan di RSUP Sanglah.

Hasil. Hasil USCOM pada 69 subjek menunjukkan rerata cardiac index, systemic vascular index, kontraktilitas jantung, dan tingkat perfusi yang rendah, yaitu $3,03( \pm 1,06) \mathrm{L} / \mathrm{min} / \mathrm{m}^{2}, 27,4( \pm 9,7) \mathrm{ml} / \mathrm{m}^{2}, 0,92( \pm 0,27) \mathrm{m} / \mathrm{s}, 474( \pm 188) \mathrm{ml} / \mathrm{min}$, dengan rerata afterload yang sangat tinggi, yaitu $2.409( \pm 950) \mathrm{ds} \mathrm{cm}^{-5} \mathrm{~m}^{2}$.

Kesimpulan. Terdapat hasil USCOM serupa pada SSD kompensata maupun dekompensata, dengan luaran syok hipodinamik. Kewaspadaan tentang komplikasi yang akan terjadi pada tiap kasus SSD dapat membantu klinisi untuk mencapai luaran yang lebih baik. Sari Pediatri 2020;21(6):371-6

Kata kunci: sindrom syok dengue, anak, USCOM, pemantauan hemodinamik

\section{Hemodynamic Profile in Children with Dengue Shock Syndrome Using Ultrasonic Cardiac Output Monitor}

Ida Bagus Gede Suparyatha, Siska Permanasari Sinardja, I Nyoman Budi Hartawan, I Wayan Gustawan, Dyah Kanya Wati, I Made Gede Dwi Lingga Utama

Background. Monitoring hemodynamic status clinically in dengue shock syndrome (DSS) cases in children is still challenging. Hemodynamic measurement with USCOM could be useful to measure real-time cardiac performance and hemodynamic status quantitatively. Hence, adequate intervention will be approached to decrease morbidity.

Objective. To present hemodynamic profile of children with DSS quantitatively.

Methods. A pilot study in 2016, measured hemodynamic status using USCOM. Data were obtained when diagnosis of DSS was confirmed at Sanglah Hospital Denpasar.

Result. USCOM results of 69 subjects showed low mean cardiac index, systemic vascular index, cardiac contractility, and perfusion levels as $3.03( \pm 1.06) \mathrm{L} / \mathrm{min} / \mathrm{m}^{2}, 27.4( \pm 9.7) \mathrm{ml} / \mathrm{m}^{2}, 0.92( \pm 0.27) \mathrm{m} / \mathrm{s}$, and $474( \pm 188) \mathrm{ml} / \mathrm{min}$ respectively, with very high mean afterload level as 2,409 $( \pm 950) \mathrm{ds} \mathrm{cm}^{-5} \mathrm{~m}^{2}$.

Conclusion. Similar USCOM results were found in both compensated and decompensated DSS, with hypodynamic shock pattern. Awareness of complications that may occur based on these findings could help clinicians achieve better outcomes. Sari Pediatri 2020;21(6):371-6

Keywords: dengue shock syndrome, pediatric, USCOM, and hemodynamic monitoring

Alamat korespondensi: Ida Bagus Gede Suparyatha. Departemen Ilmu Kesehatan Anak Fakultas Kedokteran Universitas Udayana. Jalan Kesehatan, Denpasar, Bali 80114. Email: íbgsuparyatha@yahoo.com 
S indrom syok dengue merupakan respon tubuh dalam mengompensasi kegagalan perfusi melalui jalur neurohumoral untuk mencegah hipoperfusi organ vital. Sistem kardiovaskular mempertahankan sirkulasi melalui peningkatan volume sekuncup, peningkatan detak jantung, dan vasokonstriksi perifer. ${ }^{1}$

Kontraktilitas atau inotropi jantung sangat penting dalam mempertahankan hemodinamik. Jantung harus merespon terhadap perubahan preload dan afterload untuk mempertahankan volume sekuncup yang normal melalui variasi inotropi. Mengetahui kondisi hemodinamik dan kontraktilitas jantung secara kuantitatif pada pasien SSD tentu akan memudahkan klinisi memberikan terapi secara komprehensif.

Tujuan penelitian ini adalah untuk mengumpulkan data hemodinamik menggunakan alat ukur yang canggih, non-invasif, serta mudah dilakukan, untuk memantau curah jantung dalam kasus SSD. Ultrasonic cardiac output monitor (USCOM) adalah teknologi doppler non-invasif baru yang menggunakan gelombang ultrasonik doppler transpulmonal atau transaorta untuk mengukur curah jantung, yang dipengaruhi oleh volume sekuncup dan laju jantung. ${ }^{2}$

Menilai curah jantung dengan menggunakan alat ini mudah untuk dilakukan, mudah dipelajari, selalu tersedia, bersifat real-time, dan dapat dilakukan secara berulang tanpa memberikan beban biaya tambahan pada pasien sehingga dapat digunakan sebagai alat pemantauan yang lebih baik dalam mendeteksi penurunan curah jantung, agar intervensi dan manajemen yang lebih baik dapat dilakukan sesegera mungkin. ${ }^{2}$

\section{Metode}

Penelitian ini merupakan pilot study yang dilakukan pada April hingga Agustus 2016 di RSUP Sanglah, Denpasar, Bali. Tujuan penelitian adalah untuk mengetahui profil hemodinamik SSD menggunakan USCOM. Kriteria inklusi adalah semua anak yang terdiagnosis SSD berusia 1 bulan sampai 18 tahun yang dirawat di instalasi rawat darurat (IRD), unit perawatan intensif anak (UPIA), dan intermediate ward (IW) anak dengan persetujuan dari orang tua. Kriteria eksklusi adalah penyakit jantung bawaan dan penyakit hematologi seperti leukemia, talasemia, anemia hemolitik, anemia aplastik, anemia sel sabit, sindrom myelodisplasia, dan limfoma.
Data karakteristik mencakup usia, jenis kelamin, status gizi, status rujukan, onset demam, onset ekstremitas dingin, kondisi klinis serta morbiditas seperti asites, efusi pleura, dan manifestasi perdarahan. Tanda vital dan temuan laboratorium diperoleh pada saat awal pasien terdiagnosis SSD. Curah jantung dan profil hemodinamik lainnya diukur secara kuantitatif menggunakan USCOM, terdiri dari cardiac index, preload, kontraktilitas, afterload, dan perfusi.

Probe USCOM diletakkan di cekungan jugular untuk mengukur parameter hemodinamik melalui pindaian transaorta. Setiap subjek dinilai tiga kali berturut-turut untuk mendapatkan data yang paling representatif. Hasil pengukuran direkam secara otomatis. Pemeriksaan ini merupakan prosedur tanpa rasa nyeri dan mencerminkan kondisi secara real-time. Karakteristik lainnya yang diukur antara lain berat badan, tinggi badan, tekanan darah, kadar hemoglobin, dan saturasi oksigenasi perifer. Penelitian ini disetujui oleh Komite Etik Penelitian Universitas Udayana/RSUP Sanglah dengan ethical clearance no. 410/UN.14.2/KEP/2016.

\section{Hasil}

Sebanyak 69 subjek SSD memenuhi kriteria inklusi dan eksklusi pada penelitian ini. Sebagian besar subjek adalah perempuan $(56,5 \%)$ dan berusia lebih dari lima tahun $(68,1 \%)$. Status malnutrisi (gizi lebih, obesitas, dan gizi kurang) mendominasi hingga 57,9\%; tidak ditemukan subjek dengan status nutrisi gizi buruk pada penelitian ini.

Sebanyak 52 subjek $(75,3 \%)$ memiliki riwayat infeksi dengue sebelumnya berdasarkan anamnesis orangtua. Sindrom syok dengue dekompensata merupakan manifestasi klinis terburuk dari demam berdarah yang disertai syok. Sebanyak 5 subjek $(7,2 \%)$ meninggal akibat komplikasi dan didiagnosis sebagai SSD dekompensata pada saat awal datang ke IRD anak. Sebagian besar subjek datang pada hari keempat demam $(33,3 \%)$, tetapi terdapat masingmasing 1 subjek yang datang pada hari ketujuh dan hari kedelapan demam. Karakteristik subjek tertera pada Tabel 1.

Seluruh subjek didapatkan dengan ekstremitas dingin, dengan rerata onset keluhan 5,3 $( \pm 7,6)$ jam. Syok berulang terjadi pada $39,1 \%$ subjek dengan delirium $(68,1 \%)$ merupakan temuan klinis paling 
umum. Temuan klinis penting lainnya adalah hepatomegali $(43,4 \%)$ dan perdarahan mukosa $(21,7 \%)$. Hanya sebesar $4,3 \%$ subjek mengalami asites, $2,8 \%$ edema paru, dan $7,2 \%$ efusi pleura, yang dapat memperburuk usaha napas pada pasien SSD.

Hasil laboratorium pada saat SSD ditegakkan menunjukkan bahwa sebagian besar subjek memiliki rerata kadar leukosit yang normal $\left(9,06 \mathrm{sel} / \mathrm{mm}^{3}\right)$, dengan hematokrit dan hemoglobin yang tinggi $(42,7 \%$ dan $12,97 \mathrm{~g} / \mathrm{dL})$. Rerata kadar platelet saat subjek mengalami fase syok adalah di bawah $50 \mathrm{sel} /$

Tabel 1. Karakteristik subjek penelitian

\begin{tabular}{|c|c|}
\hline Variabel & $\mathrm{n}(\%)=69$ \\
\hline \multicolumn{2}{|l|}{ Karakteristik dasar } \\
\hline Usia $>5$ tahun & $47(68,1)$ \\
\hline Jenis kelamin perempuan & $39(56,5)$ \\
\hline Diagnosis SSD kompensata & $42(60,8)$ \\
\hline Status malnutrisi & $40(57,9)$ \\
\hline Riwayat infeksi dengue sebelumnya & $52(75,3)$ \\
\hline \multicolumn{2}{|l|}{ Hari demam } \\
\hline 4 & $23(33,3)$ \\
\hline 5 & $16(23,1)$ \\
\hline 6 & $10(14,4)$ \\
\hline Meninggal & $5(7,2)$ \\
\hline \multicolumn{2}{|l|}{ Temuan klinis dan laboratorium } \\
\hline Delirium & $47(68,1)$ \\
\hline Perdarahan mukosa & $15(21,7)$ \\
\hline Efusi pleura & $5(7,2)$ \\
\hline Edema paru & $2(2,8)$ \\
\hline Asites & $3(4,3)$ \\
\hline Hepatomegali & $30(43,4)$ \\
\hline Syok berulang & $27(39,1)$ \\
\hline Ekstremitas dingin, jam ${ }^{+}$ & $5,3( \pm 7,6)$ \\
\hline Leukosit, sel $/ \mathrm{mm}^{3+}$ & $9,06(5,0)$ \\
\hline Hemoglobin, $\mathrm{g} / \mathrm{dL}^{+}$ & $13,97(2,87)$ \\
\hline Hematokrit, $\%^{+}$ & $42,7(9,06)$ \\
\hline Platelet, sel $/ \mathrm{mm}^{3+}$ & 47,17 \\
\hline Hemodinamik (USCOM) & $(43,01)$ \\
\hline Cardiac index, $\mathrm{L} / \mathrm{menit} / \mathrm{m}^{2+}$ & $3,03(1,06)$ \\
\hline Curah jantung, L/menit ${ }^{+}$ & $2,6(1,05)$ \\
\hline \multicolumn{2}{|l|}{ Preload, } \\
\hline $\mathrm{SVI}, \mathrm{ml} / \mathrm{m}^{+}$ & $27,4(9,7)$ \\
\hline FTc, $\mathrm{ms}^{+}$ & $351(41,05)$ \\
\hline Kontraktilitas, VPk, m/s ${ }^{+}$ & $0,92(0,27)$ \\
\hline Afterload, SVRI, ds $\mathrm{cm}^{-5} \mathrm{~m}^{2+}$ & $2,409(950)$ \\
\hline Perfusi, $\mathrm{DO}_{2} \mathrm{ml} / \mathrm{min}^{+}$ & $474(188)$ \\
\hline
\end{tabular}

${ }^{+}$Rerata \pm SD $\mathrm{mm}^{3}\left(47,17 \mathrm{sel} / \mathrm{mm}^{3}\right)$ dengan manifestasi klinis yang berbeda-beda.

Profil hemodinamik dibagi menjadi dua kelompok berdasarkan derajat keparahan SSD (Gambar 1). Lebih dari 85\% pada kedua kelompok memiliki hasil cardiac index yang rendah, mewakili sirkulasi yang buruk pada SSD. Cardiac index yang normal ataupun tinggi masih dapat ditemukan pada kelompok SSD kompensata sebanyak $7,1 \%$, tetapi pada kelompok dekompensata tidak ditemukan satupun subjek dengan cardiac index yang tinggi.
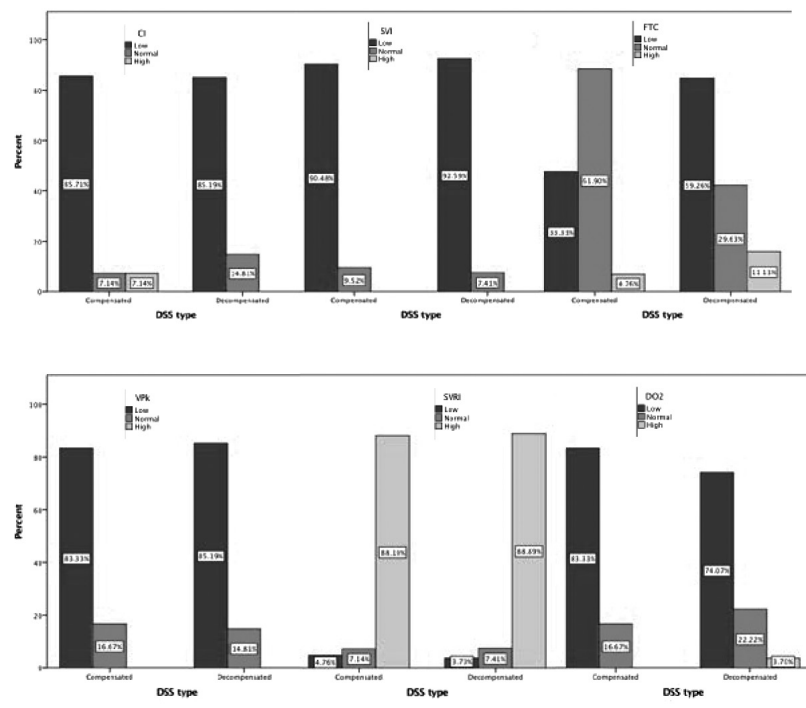

Gambar 1. Profil hemodinamik pasien SSD berdasarkan pemeriksaan USCOM

Preload merupakan pengisian ventrikel, dan volume sekuncup sangat bergantung pada inotropik untuk mengisi volume preload. Preload dibagi menjadi 2 komponen, antara lain systemic vascular index (SVI) dan corrected flow time (FTc). Systemic vascular index ditemukan rendah pada kedua kelompok SSD dengan rerata $28,7 \mathrm{ml} / \mathrm{m}^{2}$ dan $25,3 \mathrm{ml} / \mathrm{m}^{2}$ pada SSD kompensata dan dekompensata. Rerata FTc didapatkan normal pada SSD kompensata $(357,1 \mathrm{~ms})$ dan rendah pada SSD dekompensata.

Berbanding terbalik dengan preload, volume afterload yang tinggi ditemukan pada sebagian besar subjek. Afterload diwakili oleh systemic vascular resistance index (SVRI) pada USCOM dengan volume $2.292 \mathrm{ds} \mathrm{cm}^{-5} \mathrm{~m}^{2}$ dan $2.590 \mathrm{ds} \mathrm{cm}^{-5} \mathrm{~m}^{2}$ pada kelompok kompensata dan dekompensata (Tabel 2). Peningkatan SVRI akan menambah beban jantung dan memengaruhi volume sekuncup. 
Ida Bagus Gede Suparyatha dkk: Profil hemodinamik anak dengan sindrom syok dengue berdasarkan pemeriksaan USCOM

Tabel 2. Rerata, median, dan perbedaan rerata pada kedua kelompok

\begin{tabular}{|c|c|c|c|c|c|}
\hline \multirow{2}{*}{ Variabel } & \multicolumn{2}{|c|}{ SSD } & \multirow[b]{2}{*}{ Nilai $\mathrm{p}$} & \multirow[b]{2}{*}{ Perbedaan rerata } & \multirow[b]{2}{*}{ IK 95\% } \\
\hline & Dekompensata & Kompensata & & & \\
\hline \multicolumn{6}{|l|}{ Sirkulasi ${ }^{*}$} \\
\hline \multicolumn{6}{|l|}{ Cardiac index, $\mathrm{L} / \mathrm{min} / \mathrm{m}^{2}$} \\
\hline \multicolumn{6}{|l|}{ Preload $^{+}$} \\
\hline $\mathrm{SVI}, \mathrm{ml} / \mathrm{m}^{2}$ & $2,7(1,2-5,4)$ & $2,65(1,8-6,5)$ & 0,436 & $-0,2056$ & $-0,7296-(0,3185)$ \\
\hline FTc, ms & $25,3(9,4)$ & $28,7(9,7)$ & 0,165 & $-3,3492$ & $-8,1127-(1,4142)$ \\
\hline Kontraktilitas $^{+} \mathrm{VPk}, \mathrm{m} / \mathrm{s}$ & $341(50,1)$ & $357,1(33,1)$ & 0,155 & $-15,820$ & $-37,866-(6,226)$ \\
\hline \multicolumn{6}{|l|}{ Afterload ${ }^{+}$} \\
\hline SVRI, $\mathrm{d} s \mathrm{~cm}^{-5} \mathrm{~m}^{2}$ & $0,8(0,56-1,60)$ & $0,92(0,40-81)$ & 0,844 & $-0,01341$ & $-0,14860-(0,12177)$ \\
\hline Perfusi $^{+}$ & $2.590(1.221,2)$ & $2.292(719,9)$ & 0,206 & 297,974 & $-168,070-(764,017)$ \\
\hline $\mathrm{DO}_{2}, \mathrm{ml} / \mathrm{min}$ & $472,4(248,1)$ & $476,2(141,5)$ & 0,942 & $-3,831$ & $-110,242-(102,581)$ \\
\hline
\end{tabular}

${ }^{+}$Rerata $\pm \mathrm{SD},{ }^{*}$ median (min-maks)

Preload yang rendah dan afterload yang tinggi merupakan temuan yang sesuai dengan klinis penderita yang mengalami syok hipovolemik pada SSD, dimana ditemukan akral dingin dan perabaan nadi yang lembut pada sisi perifer tubuh. Untuk mempertahankan curah jantung yang normal dalam kondisi syok tersebut, kontraktilitas jantung memainkan peran penting untuk memperbaiki sirkulasi dan memenuhi kebutuhan oksigen jaringan. Mengetahui keadaan kontraktilitas jantung pada fase SSD dapat membantu klinisi untuk mempertimbangkan obat inotropi.

Pada penelitian ini, seluruh subjek memiliki kontraktilitas jantung yang rendah, yaitu $0,92 \mathrm{~m} / \mathrm{s}$ dan $0,8 \mathrm{~m} / \mathrm{s}$ pada kelompok SSD kompensata dan dekompensata yang diwakili oleh peak velocity (VPk). Profil hemodinamik subjek tercantum pada Gambar 1 dan dianalisis lebih lanjut sebagai luaran sekunder untuk melihat perbedaan rerata temuan hemodinamik pada kedua kelompok tersebut (Tabel 2).

Parameter hemodinamik harus dibandingkan dengan rentang normal berdasarkan usia untuk mendapatkan interpretasi yang baik. Garis besar temuan, antara lain, cardiac index, kontraktilitas jantung, dan tingkat perfusi yang rendah pada SSD anak (Gambar 1). Hasil tersebut bahkan lebih rendah dari rentang batas normal pada populasi neonatus.

Rerata afterload pada penelitian ini ditemukan sangat tinggi, lebih tinggi daripada batasan normal pada kelompok usia manapun untuk populasi pediatri.

\section{Pembahasan}

Penelitian ini mendapatkan rendahnya inotropi pada sebagian besar subjek, dengan median cardiac index dan curah jantung yang rendah. Di sisi lain, rerata afterload didapatkan dengan hasil yang sangat tinggi, menunjukkan adanya vasokonstriksi perifer sebagai kompensasi dari kondisi hipovolemik tubuh. Curah jantung yang rendah dan afterload yang tinggi dalam penelitian ini menunjukkan bahwa SSD umumnya merupakan syok hipodinamik.

Syok hipodinamik adalah tipe syok yang umum terjadi pada SSD. Pada beberapa subjek terdapat cardiac index normal, yang mencerminkan tubuh masih mampu mengompensasi kegagalan perfusi jaringan. ${ }^{3}$ Namun, penurunan inotropi sebagian besar diikuti oleh peningkatan afterload, sehingga cardiac index yang normal tidak serta merta mencerminkan hemodinamik yang normal.

Pada penelitian ini ditemukan perbedaan yang mencolok pada SSD dekompensata, di mana tidak terdapat satupun subjek yang memiliki cardiac index, SVI, dan VPk yang tinggi. Hal ini mencerminkan buruknya hemodinamik SSD dekompensata dibandingkan kompensata.

Sebanyak 90,48\% dan 92,5\% subjek SSD kompensata dan dekompensata memiliki preload yang rendah, sesuai dengan patofisiologi SSD itu sendiri. Hal ini dapat menjadi acuan terapi jika diikuti secara serial, dengen mempertimbangkan keseluruhan variabel pada USCOM lainnya, seperti kontraktilitas jantung dan keadaan vaskuler secara sistemik. Kontraktilitas jantung yang tidak memadai, serta pemberian cairan yang berlebihan tanpa evaluasi tentu akan menambah morbiditas pasien.

Pada penelitian observasional retrospektif di Malang, stroke volume variation (SVV) digunakan untuk mewakili keadaan preload pada pasien SSD sebagai 
prediktor dalam menilai respons subjek terhadap cairan yang diberikan. Tidak ditemukan hasil yang berbeda secara bermakna pada SVV pasien SSD yang diberikan total cairan kurang atau pun lebih dari $40 \mathrm{ml} / \mathrm{kg}$, tetapi ditemukan penurunan mortalitas sebanyak $12 \%$ pada subjek yang diberikan cairan dengan restriksi maksimal $40 \mathrm{ml} / \mathrm{kg} .{ }^{3}$ Peningkatan akumulasi cairan di jaringan intersisial dan spasitas alveolar dikatakan sebagai dampak buruk pemberian resusitasi cairan secara masif. Menghitung total cairan yang diberikan dan monitor efek samping secara klinis sangatlah penting disamping melihat kadar preload pada USCOM.

Pada penelitian ini ditemukan VPk yang rendah pada kedua kelompok SSD yang mewakili keadaan inotropi saat awal terdiagnosis SSD. Tidak ada satupun subjek yang memiliki inotropi tinggi, sehingga diasumsikan terdapat gangguan kontraktilitas jantung pada fase syok tersebut.

Mekanisme kerusakan jantung pada demam berdarah masih belum banyak diketahui, tetapi teori yang berkembang adalah invasi langsung pada miosit oleh virus dan kerusakan sel jantung akibat inflamasi yang menjadi mekanisme utama dari manifestasi klinis disfungsi jantung. ${ }^{4}$

Sebuah penelitian observasional prospektif di Yogyakarta menemukan sebagian besar subjek SSD memiliki cardiac index yang rendah dan refrakter terhadap cairan berdasarkan temuan USCOM. ${ }^{5}$ Sebagian besar subjek pada penelitian tersebut menunjukkan rendahnya inotropi dan afterload. Berbeda dengan temuan pada penelitian ini, afterload ditemukan tinggi pada hampir seluruh subjek dengan mayoritas inotropi yang rendah.

Pada keadaan syok, tubuh akan melakukan kompensasi melalui proses vasokonstriksi pembuluh darah perifer. ${ }^{6,7}$ Jika berlangsung lama akan terjadi peningkatan SVR secara sistemik. ${ }^{8}$ Pada penelitian ini ditemukan peningkatan SVRI yang ekstrem pada keseluruhan subjek, di mana $88,1 \%$ dan $88,89 \%$ subjek SSD kompensata dan dekompensata mengalami vasokonstriksi hebat. Jika systemic vascular resistance naik, maka jantung harus berkontraksi lebih kuat untuk menghasilkan volume sekuncup yang stabil. Ventrikel akan mengalami dilatasi dan kegagalan fungsi bila tidak mampu mengompensasi vasokonstriksi arteri. ${ }^{7,9}$

Pada penelitian ini ditemukan 5 dari 69 subjek mengalami kematian, di mana seluruh subjek tersebut memiliki kadar trombosit di bawah $20 \mathrm{sel} / \mathrm{mm}^{3}$ saat awal datang. Empat dari 5 subjek tersebut memiliki perdarahan saluran cerna dan datang ke IRD anak saat hari ke-5 demam. Satu subjek datang pada hari ke-3 demam, dan memiliki riwayat infeksi dengue sebelumnya.

Tiga dari 5 subjek yang meninggal berusia kurang dari 5 tahun. Tingginya mortalitas pada anak yang lebih muda dikaitkan dengan endotel kapiler yang mudah dipengaruhi oleh sitokin sehingga mudah terjadi peningkatan permeabilitas. ${ }^{10}$ Pada hasil USCOM, seluruh subjek yang meninggal memiliki cardiac index, SVI, dan VPk yang rendah, serta SVRI yang terlampau tinggi, dimana hasil tersebut tidak berbeda pada temuan mayoritas subjek yang hidup. Namun, terdapat 7 subjek mengalami syok berulang dan 1 syok refrakter yang memiliki luaran hidup pasca pemberian inotropi. Temuan ini menjadi pertimbangan terapi obat inotropi mungkin dapat dipertimbangkan pada kasus sulit yang tidak membaik pasca resusitasi cairan, dengan memantau klinis serta hemodinamik secara kuantitatif menggunakan USCOM sebagai acuan.

Penelitian ini tidak memiliki data mengenai kontraktilitas jantung dan status hemodinamik sebelum atau setelah onset SSD untuk membandingkan perubahan profil hemodinamik yang terjadi selama perawatan. Pemeriksaan serial dan investigasi lebih lanjut diperlukan untuk memberikan pemahaman yang lebih baik.

\section{Kesimpulan}

Luaran hemodinamik yang buruk ditemukan serupa pada kelompok SSD dekompensata dan kompensata. Obat inotropik harus dipertimbangkan pada keadaan SVI dan VPk yang rendah, terutama pada pasien yang tidak responsif terhadap terapi cairan.

Pemantauan status hemodinamik menggunakan USCOM dapat membantu klinisi dalam memberikan terapi sesuai kebutuhan. Kejadian syok berulang dan syok refrakter merupakan kondisi yang lebih rumit dan memerlukan perhatian yang lebih besar. Pencegahan berkembangnya DBD menjadi SSD merupakan poin penting, mengingat luaran hemodinamik yang buruk ditemukan pada SSD kompensata dan dekompensata.

\section{Daftar pustaka}

1. UKK Infeksi dan Penyakit Tropis Ikatan Dokter Anak Indonesia. Buku pedoman diagnosis dan tata laksana infeksi virus 
dengue pada anak. Hadinegoro R. S., Moedjito Ismoedijanto, Chairulfatah Alex, penyunting. .Jakarta: Badan Penerbit IDAI; 2014.

2. Horster S, Stemmler HJ, Strecker N, dkk. Cardiac output measurements in septic patients: comparing the accuracy of USCOM to PICCO. Crit Care Res Pract 2012:1-5.

3. Yuliarto S, Kadafi KT, Anitasari D. Restrictive versus liberal fluid resuscitation in children with dengue shock syndrome: the differences in clinical outcomes and hemodynamic parameters. Int J Pediatr 2019;7:9215-24.

4. Wichmann D, Kularatne S, Ehrhardt S, Wijesinghe S, Brattig NW, Abel W, Burchard GD. Cardiac involvement in dengue virus infections during the 2004/2005 dengue fever season in Sri Lanka. Southeast Asian J Trop Med Pub Health 2009;40:727-30.

5. Rusmawatiningtyas D, Wiguna PA, Kumara IF, Nurnaningsih, Yuliarto S, Arguni E, dkk. Initial hemodynamic profile of children with dengue shock syndrome in referral settings. Am J Pediatr 2019;5:260-6.

6. Nichols DG, Shaffner DH. Roger's textbook of pediatric intensive care Edisi ke-5. Philadelphia: Wolter Kluwer; 2016.h.:1091-99.

7. Kirawittaya T, Yoon IK, Wichit S, dkk. Evaluation of cardiac involvement in children with dengue by serial echocardiographic studies. Negl Trop Dis 2015;9:3943.

8. Nichols DG, Shaffner DH. Roger's textbook of pediatric intensive care. Edisi ke-5. Philadelphia: Wolter Kluwer; 2016.h.1120-31.

9. Smith BE, Madigan VM. Non-invasive method for rapid bedside estimation of inotropy: theory and preliminary clinical validation. Brit J Anaesth:2013;4:580-8.

10. Papalkar PV, Sarode RR, Acharya S, Kumar S. Cardiac Manifestations in Dengue. Indian J Med Spec 2019;10:304 . 